\title{
Typological and constructive transformations of spatial structures in Mexico. The Sports Palace for the XIX Olympics
}

\author{
Transformaciones tipológicas y constructivas de las estructuras espaciales en México. El Palacio de \\ los Deportes para la XIX Olimpiada
}

\author{
Edwin González Meza (Main and contact autor) \\ Universidad Politécnica de Madrid, ETSAM, Departamento de Construcción y Tecnología Arquitectónicas, España. \\ Avenida de Juan de Herrera, 4, 28040 Madrid, España. (00 34) 913366501 \\ e.gmeza@alumnos.upm.es

\section{Jesús Anaya Díaz} \\ Universidad Politécnica de Madrid, ETSAM, Departamento de Construcción y Tecnología Arquitectónicas, España. \\ jesus.anaya@upm.es
}

Manuscript Code: 583

Date of Acceptance/Reception: 07.09.2016/27.01.2015

\begin{abstract}
Spatial structures have shown a great development, mainly since the post-war years from the middle of the twentieth century. They have become a constructive solution which provides lightness and stiffness, while achieving longer spans and reducing energy and used material. In Mexico City, the Sports Palace was completed in 1968 to become a landmark of Mexican architecture and an example of a low-cost, lightweight, dome. This essay shows the geometric influences and foundation behind its design, as well as the development and typological transformation of its structural elements and materials in the finally adopted constructive solution -the crossed arch. Such solution transformed material and its geometry into a structural typological solution of its own. Here, Félix Candela used constructive and structural elements, previously experienced in other typologies, into solutions to form new types. This way, Candela developed the hyperbolic paraboloid, employing new materials and applying geometry for the structural typological development of the shape of the Sports Palace, achieving a dome which would become a typological model of international architecture.
\end{abstract}

Keywords: Grid structures, light structures, arch structure, hyperbolic paraboloid, shell structures.

Resumen

Las estructuras espaciales han mostrado una gran evolución, principalmente desde los años de la posguerra a mitad del siglo XX. Estas estructuras se han convertido en una solución constructiva que otorga ligereza y rigidez, logrando obtener mayores luces y reduciendo el consumo de energía y de materiales. En la Ciudad de México se concluyó el Palacio de los Deportes en el año de 1968 para convertirse en un hito de la arquitectura mexicana y un ejemplo de cubierta aligerada de bajo costo. En este documento se mostrará las influencias y bases geométricas para su diseño, así como su evolución y transformación tipológica de sus elementos estructurales y materiales adoptando al final la solución constructiva de arcos cruzados. Esta solución por si misma transformo el material y su geometría en una solución tipológica. Aquí, Félix Candela utiliza elementos constructivos y estructurales, previamente experimentados en otras tipologías, en soluciones para formar nuevos tipos. De esta manera, Candela desarrolló el paraboloide hiperbólico, el empleo de nuevos materiales y la aplicación de la geometría para el desarrollo tipológico estructural de la forma del Palacio de los Deportes, logrando una cúpula que se convertiría en un modelo tipológico de la arquitectura internacional.

Palabras clave: Estructuras ligeras, estructuras ligeras, estructura de arco, paraboloide hiperbólico, estructuras de cascara.

State of the Art

Introduction of the developed constructive typology.

The designation of Mexico as organizer of the Olympics took place on October 18th, 1963, at the 60th General Session of the International Olympic Committee in Baden-Baden, Germany. Mexico City based its petition on existing facilities, and on its experience in organizing previous events -which would reduce the cost of investment in the construction of new facilities- and was officially awarded the host of the XIX Olympic Games (Comite Organizador de los juegos olimpicos XIX, 1969).

The Olympics in Mexico constituted a significant change for Mexican architecture, which accelerated the arrival of modernity by means of encouraging the regenerative aspirations of the architects by the time. As a driver of change in the field of architecture, the Games elated designers to propose projects that would be functional, iconic, and avant-garde, apart from being original and modern. Thus, they leaded to the adoption of an attitude that favored innovative design in 
the competitors of the different contests. Therewith, such situation facilitated their relevance on an international level. In addition to this, projects were influenced by the successful architectural works developed by Nervi and Tange for the former games, which were taken as an example by the Organizing Committee for the definition of a basis for the different competitions.

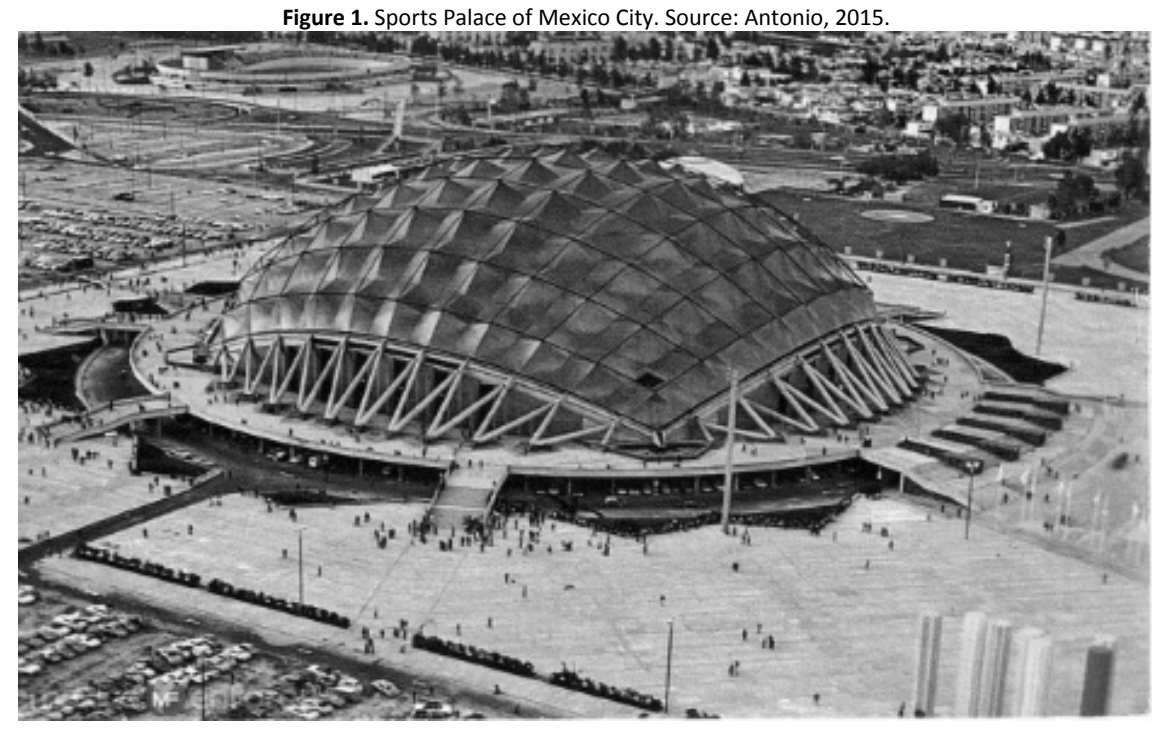

In the competition developed by the SOP [Secretaría de Obras Públicas], Félix Candela Outeriño, in cooperation with Enrique Castañeda Tamborel, and Antonio Peyrí Macià, designed a new structural proposal, that resulted in the winning preliminary draft "Corpore Sano" (Fernández Contreras, 2011). Designed with a capacity for 23,000 spectators (Candela, Peyri, \& Castañeda, 1967; Velázquez Moreno, 1968) it extended over a constructed area of 27,461 $\mathrm{m}^{2}$ (Figure 4) (Candela, Castañeda, \& Peyrí, 1968), and became the largest indoor sports facility in Olympic history by the time (Figure 1) (Comite Organizador de los juegos olimpicos XIX, 1968).

\section{Description of the problem}

\section{Description of the project's geometry}

According to Félix Candela's own words, "the essential purpose of structure -that property which defines it as such-is to transform external loads into internal stresses and to transmit these, distributed along the structural members, to convenient locations" (Candela, 1954). In his Sports Palace in Mexico City, Candela used geometry, together with an innovative structural proposal, to solve a long-span roof structure which, according to classifications by different authors (Bradshaw, Campbell, Gargari, Mirmiran, \& Tripeny, 2002), can be described as a special structure of a horizontal type (Meza \& Diaz, 2013), shaping a gridded dome that projected over a rotational surface. The result was a spherical grid as a solution for the lattice of the metallic frameworks (Schueller, Heck, \& de Strasbourg, 1983).

The reticular dome of the Sports Palace consists of 22 frameworks, shaped in the form of a tied arch with diagonal struts in their centers, forming an orthogonal lattice of crossed arches with a section of a height of $5 \mathrm{~m}$. The grid of the supporting structure of the arches is disposed in great circles of a sphere (Álvarez \& González Pozo, 1968; Candela et al. 1968) reaching a maximum radius of $95.10 \mathrm{~m}$ (Moreno Aguirre, 1969) and a radius of $92.60 \mathrm{~m}$ to the axis of the framework (De Buen, 1968). The structure is limited by four inclined planes that contain the polar axes, which form together a dihedral angle of $45^{\circ} 28^{\prime}$ with the vertical plane (Murad Silva, 1967). The dome can be assumed as working on compression, due to being situated within $52^{\circ}$ of the angle with the vertical plane (Figure 2). In the shorter spans covered by the structure, its lateral arches reach $132 \mathrm{~m}$, while its maximum spans are located in its central arches, covering $193 \mathrm{~m}$ (De Pablo, 1968), which considerably exceeds the distances previously designed and built by Candela by that time (Figure 
4). The applied typology of crossed arches over an orthogonal grid solved the stabilization of the structure against horizontal loads by triangulating its elements. It is important to consider that the method of deformations was used for the grid analysis of the dome, which consists in obtaining the matrix of stiffness of the inverted structure $(\mathrm{k})$ that, multiplied by the forces (F), provides the displacements $(x)$. Hereby the deformations of its members $(e)$ and stresses $(p)$ could be obtained (Figure 3) (Damy Rios, 1968).

Figure 2. a) Drawing of the grid of the Sports Palace using great circles of a sphere. Source: Self-elaboration (2015); b) Drawing and section of the frameworks (De Buen, 1968).

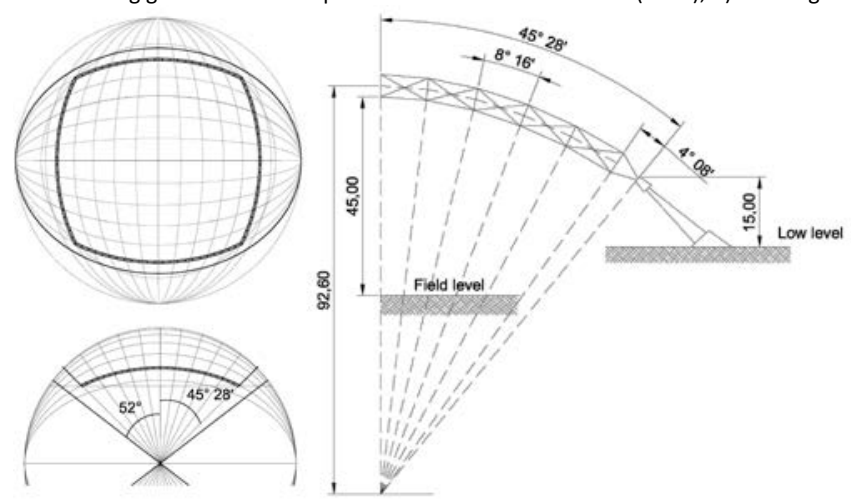

Figure 3. Sketch of the grid analysis using the deformation method (Damy Rios, 1968).

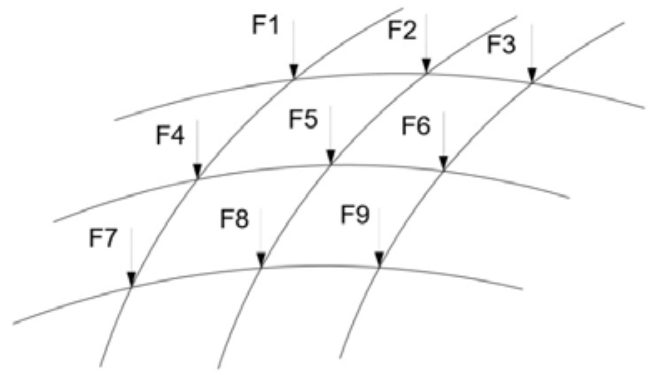

$\mathrm{x}=\mathrm{x}^{-1} F \quad(F=\mathrm{x} \mathrm{x})$

$e=a \mathrm{x}$

$p=k e$

Where: $\mathrm{x}=$ Nodal displacement; $F=$ Strength in the nodes; $\mathrm{x}=$ Stiffness matrix on the grid; $e=$ Deformation in the members. $a=$ Continuity matrix; $k=$ Stiffness matrix of the members; $p=$ Stresses on the members.

Various factors interfered in the project of the main structure, influencing the design of the frameworks, the materials used for its manufacture, and the grid finally used. These factors were: a) the earthquakes, as Mexico City is located in the center of the country, an area that is considered a region of moderate to high seismic activity; b) the poor quality of land where it would be built, being a land of low resistance suffering from sinking, which required a partially compensated foundation on specially designed piles of friction and end, with a total of 1407 piles with a length of $39 \mathrm{~m}$, of which $34 \mathrm{~m}$ are made of concrete and the bottom $5 \mathrm{~m}$ of metal tube of 4", and an additional excavation with a depth of $1.8 \mathrm{~m}$ realized to compensate 2.5 tons $/ \mathrm{m}^{2}$ (Moreno Aguirre, 1969; Ruiz Hernandez, 1968), for its design the values of live loads registered in the Regulation for Constructions in the Distrito Federal [D.F.] were employed, being for the dome the value for the design of vertical loads of $40 \mathrm{~kg} / \mathrm{cm}^{2}$, seismic analysis of $20 \mathrm{~kg} / \mathrm{m}^{2}$ and settlements in clay of $20 \mathrm{~kg} / \mathrm{cm}^{2}$ (Guerrero, 1968); c) furthermore, the wind played a great role, as Mexico City can suffer from winds reaching high speeds, and thus the development of wind tunnel tests was necessary, which the SOP assigned to the Instituto de Ingeniería of the UNAM [Universidad Nacional Autónoma de México], where a model of the Sports Palace was fabricated to be able to reproduce the actual wind conditions of up to $200 \mathrm{~km} / \mathrm{h}$, finally taking a designed wind speed of $120 \mathrm{~kg} / \mathrm{cm}^{2}$ (Sotelo A. \& Springall G., 1968). The result of the study was that irregularities of the roof dramatically alter the pressure distribution and make 
almost the totality of the roof work to suction of the order of $70 \mathrm{~kg} / \mathrm{m}^{2}$ (Guerrero, 1968; Sotelo \& Springall, 1968) and with the support of Eng. Julio Damy, who was a partner of Candela and specialist in computational analysis, a mathematical model was developed, only possible due to the entry of computers 10 years earlier in Mexico, and due to a stress analysis of the structure, using a software with a number of subroutines for the calculations -TRANS, ADD, MULT, MATINV, etc.with the interest to use them for the arrangements of any dimension-DIMENSION-, the applied programs were codified in FORTRAN using a IBM-709 computer (Damy Rios, 1968), on the basis on which an analog model, that would be tested in the wind tunnel, was made; d) finally the last factor to be considered were the large spans, which posed a problem of huge scale by influencing in the weight of the dome and the materials necessary for its construction. In order to detail the geometry of the 121 hyperbolic paraboloids, a computer program was developed, with which the lengths of the bends, the central angle, and the local coordinates of all the hyperbolic paraboloids, were obtained (Damy Rios, 1968).

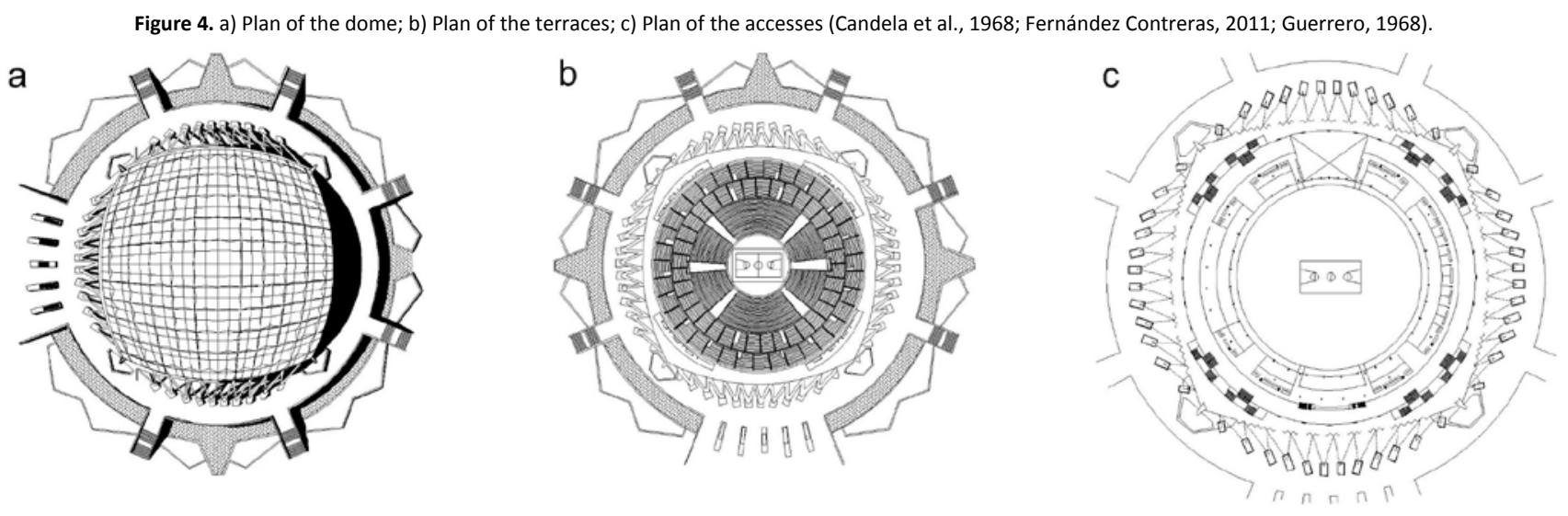

The arches of the main structure are fabricated with metallic profiles of different shapes and sizes, and metal plates of different thicknesses to form special profiles and nodes, thus solving the structural work of each of the elements. The top and bottom chords of the frameworks are manufactured with tubes of a diameter of $20 \mathrm{~cm}$, grade 30 , "working under traction enabling to withstand flexural moments caused by the wind and asymmetrical loads caused by hail, sinking, etc." (De Buen, 1968). The diagonals of the arches are built up of profiles $\mathrm{H}$ of $30 \times 30 \mathrm{~cm}$, with plates of $5 / 8$ " and a core of $1 / 2$ " of thickness, absorbing the whole compression on the arches (Candela et al., 1968; Guerrero, 1968), and the uprights of the frameworks are also made of three plates of $30 \times 15 \mathrm{~cm}$, two plates of a thickness of $3 / 4$ " and a core of $1 / 2$ ", subjected to compression (Figure 5) (De Buen, 1968; Guerrero, 1968). The vertical load test on an isolated arch showed that the stresses are of the same order on the diagonals and on the ties, where the maximum stresses do not reach $350 \mathrm{~kg} / \mathrm{cm}^{2}$. In the test of the vertical displacement of a support, it was obtained that the normal maximum average stress registered did not exceed $700 \mathrm{~kg} / \mathrm{cm}^{2}$ (Meli, Olivares, \& Esteva, 1968). Eng. Oscar De Buen established a mathematical model of the structure to confirm the sections and supports.

Due to the design of the grid dome and the frameworks working in axial compression -that transmitted the horizontal stresses and distributing the loads through the system of crossed arches, and also solved the transmission of the stresses between them- an unconventional design was possible by eliminating the secondary elements, such as the purlins (Candela et al., 1968; De Miguel, 1968). The main frameworks rest on so called tablets (Figure 5) (Moreno Aguirre, 1969) made of reinforced concrete and which, at the same time, rest on hexagonal section buttresses ( 80 in total) of reinforced concrete. Each of the tablets and buttresses are connected by beams, which also have a gutter for rainwater harvesting. The buttresses (Figure 6) have the ability to absorb lateral loads caused primarily by wind, earthquakes, and the pressure from the arches. The tablets also rest on folded walls of reinforced concrete (Figure 6) that transmit vertical loads, whose formwork was fabricated by red bricks acting thereby as dead formwork -a typical Mexican material beloved by Candela, besides its low cost and speed of execution. In the interview with PhD. Álvaro Sánchez, it was confirmed that Candela objected to leave concrete as a final finishing of the walls, knowledge that is forged based on the information generated by the experience of PhD. Álvaro Sánchez related to the supervision of the construction site he was assigned to (Ferrada \& Serpell, 2009). 
Figure 5. a) Detail of the union tablet-frameworks; b) Detail of the node of the frameworks of the chords with uprights and diagonals; c) Detail of the node between diagonals; d) Detail of the node between diagonals and aluminum structure (De Buen, 1968; Moreno Aguirre, 1969).

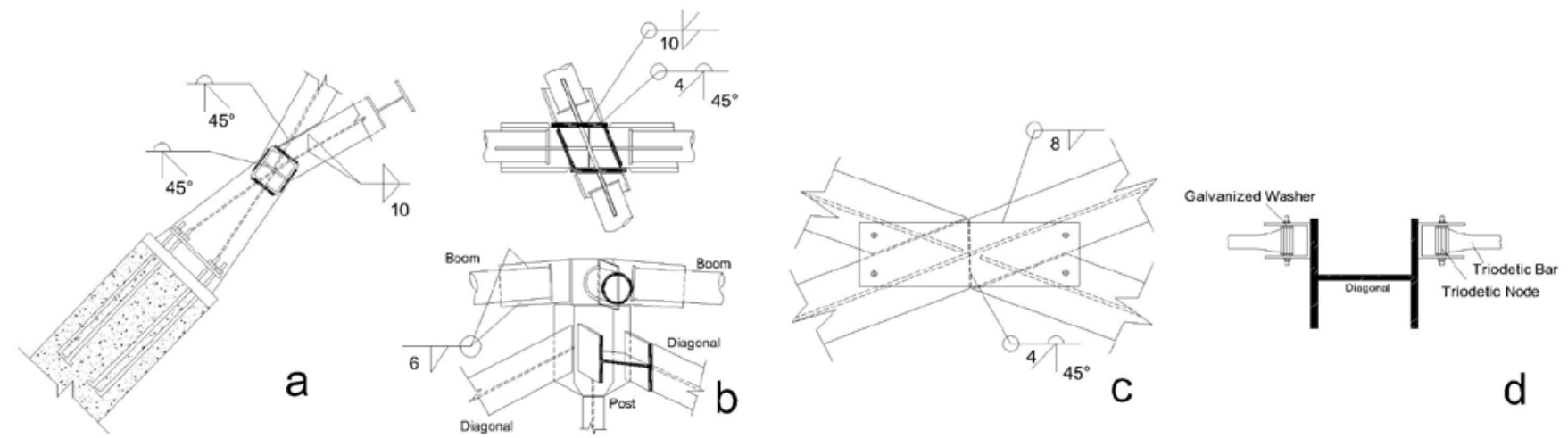

The secondary structure was made with aluminum tubular using the prefabricated Triodetic system. It was applied in the gaps, of variable dimensions, existing in the lattice of the arches (approximately $12 \mathrm{~m} \times 12 \mathrm{~m}$ ), to form hyperbolic paraboloids [hypars] based on a grid of three directions of a single layer type (Figure 7). The aluminum structure of the Triodetic system was manufactured and assembled by Eng. Francisco Castaño, who submitted his quote and construction plan to Candela, who finally approved both. The system was chosen to lighten the weight of the dome (interview with PhD. Álvaro Sánchez). Eng. Castaño worked on perfecting the concrete shells constructed by architect Félix Candela (Makowski, 1984; Ochoa \& Osorio, 1985).

Copper was applied over the dome, due to being a finishing material characterized by its low cost decking, that requires minimal maintenance. Two American workers with the required expertise were hired for its assembly, as a support and training for other local workers. The copper tiles were joined in creosoted timber to reduce the risk of fire. By recommendation of the architect Pedro Ramirez Vazquez, who mentioned that the greatest concern of architect Félix Candela was to comply with the cost of construction and completion times, PhD. Álvaro Sánchez was put in charge of the supervision of the construction site.

Methodology

\section{Typological and constructive influences on the development of the project}

The Sports Palace in Mexico City broached a complexity of the project in various factors and an architectural program that required the use of new proposals, which could give solution to the issue posed by the SOP. In the development of the new sports facilities were some factors, that favored its construction given the arrival to Mexico of an innovative milestone in the field of architecture, examples of these factors were the new technological and material advances contributed at that time by the United States, the Soviet Union, and some European countries such as England, France, and Germany, which were developing long-span structures with smaller sections and high resistance -, as well as the use of innovative construction systems and the use of new materials that resulted in outstanding architectural and structural works that would influence the development of the Olympic projects and specifically the development of the Sports Palace, with the final aim of exhibiting a modern Mexico to the world. Worldwide, large infrastructure projects and the construction of large-scale structures, would redesign the construction of large structural projects, developing the technologies and materials necessary for their construction, being an international proposal the use of hypars as a linear solution to cover the long-spans of the projects. In technology, an important factor for the development of the project was the use of electronic computers -as the IBM-650 computer, complemented by a magnetic drum- which raised its use for the execution of the final draft of the Sports Palace, since the implementation of manual calculations would have been impossible, due to the structural complexity of the project (Damy Rios, 1968).

Another factor that influenced internationally the development of light-weight structures was the end of the Second World War. By then, the absence of skilled labor, and the lack of material in the United States, together with the necessity to continue building innovative constructions, systems were developed -such as high-resistant bolts and the electric arch 
for the application of welding. F. Samuely in Britain employed welding in the mid-twentieth century as an economic solution to reduce the consumption of material.

Many of these factors would influence the work of architects worldwide, and architect Félix Candela was no exception, by using a variety of geometric shapes to solve the design and construction of his structures: short and long cylindrical sheets, catenary guideline, conoids and cones, spherical and elliptical domes, folded sheets, etc. But, apart from these more or less conventional shapes, the hypar seemed as the ideal form, in confirmation of Candela's broad knowledge over this material (Cassinello, Schlaich, \& Torroja, 2010), based on his personal experience in Mexico, developed since 1949. Candela mentioned that, "of all the ways you can give to a shell, the easiest and most practical to build are the hyperbolic paraboloids" (Candela, 1958).

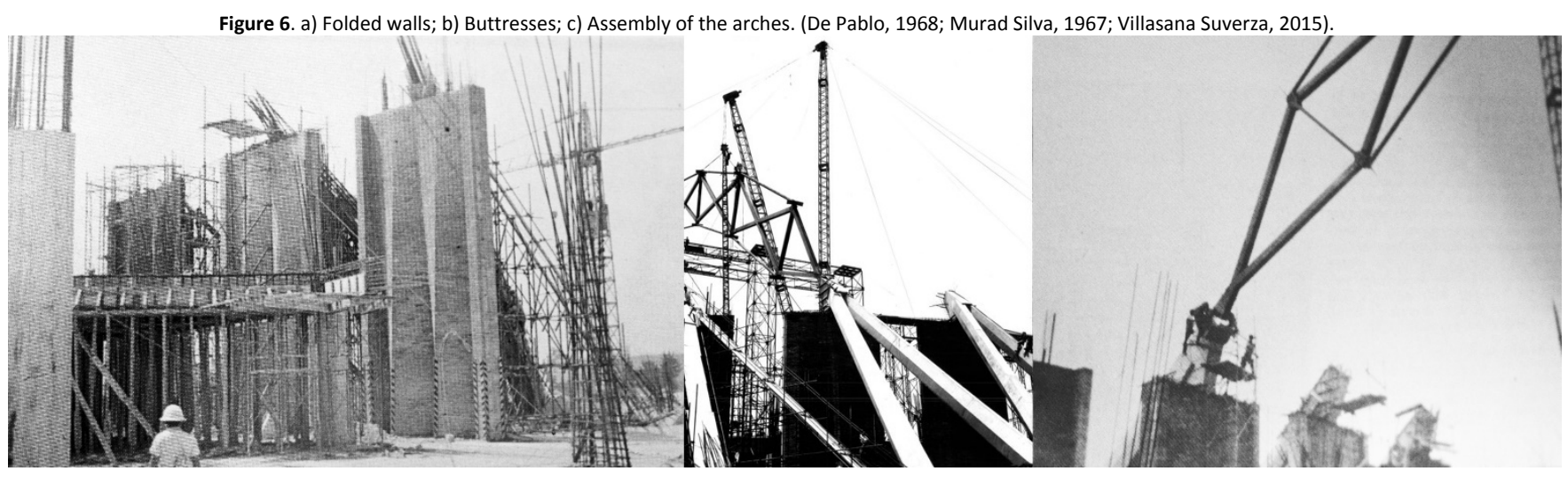

\section{The dome and hypars as typological solutions of the shape.}

In the first architectural approaches to the project of the Sports Palace, the SOP invited five renowned architects, whose structural solutions provided the answer to this architectural space. Félix Candela was one of the guests, suggesting in his first proposal the most reduced project with a capacity of just 15,000 localities: a solution based on concrete made on site and using a deck of double curvature that covered the totality of an almost round space with a diameter of 130 meters, supported on 24 double buttresses of a height of 35 meters collocated around the perimeter of the building (Figure 8) (Fernández Contreras, 2011). Candela submitted a proposal that was based on the use of hypars, which were previously designed and worked in concrete. In his proposal, a hyperbolic paraboloid can be seen in form of a saddle, imagining that the solution would be through a tensioned structure and reinforced by buttresses to withstand possible thrusts which could be generated by the tensioned deck. An example of a similar solution preceding this proposal of Candela and which could have influenced its design is the Dorton Arena constructed by Maciej Nowicki with Fred Severud as a consultant for the design of its structure, opened in 1952 in the city of Raleigh, North Carolina, being the first structural solution using cables for a deck working in tension, supported by concrete arches working in compression.

Figure 7. a) Assembly of the arches b) Sample of assembly of secondary structures over the structure of arches; b) Assembly of the deck. (Villasana Suverza, 2015).

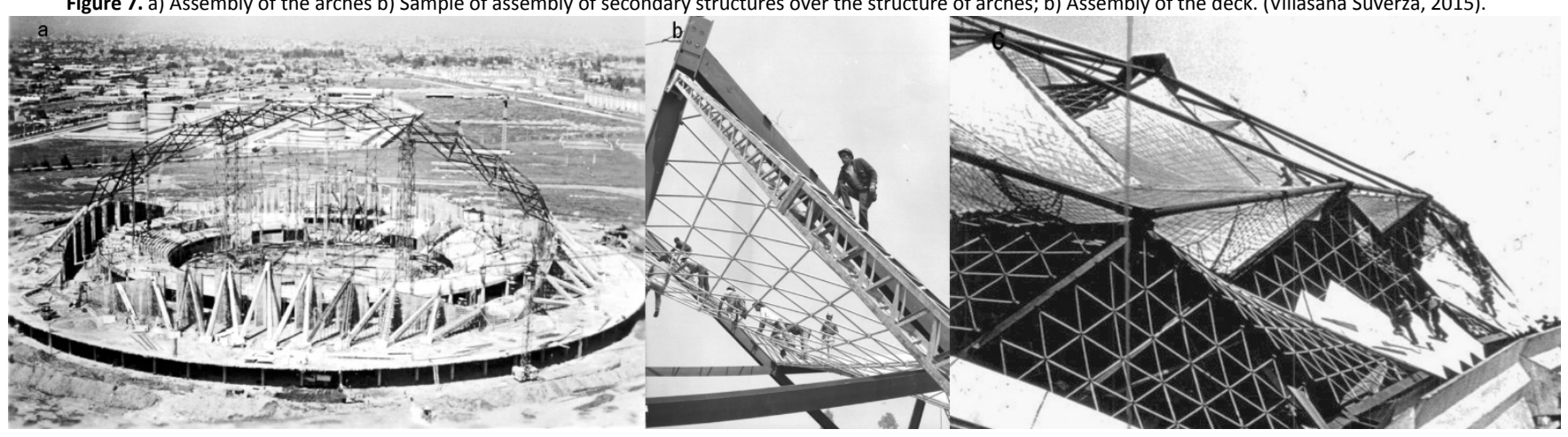


Subsequently when changes in the architectural program were realized and the capacity of the Sports Palace increased, the first proposal raised restricted the solution of the scale, because the anticlastic solution working in tension limited the free space within the maximum distance of the supports forcing to be taller, which would increase the section and height of the supports and thereby reduce the capacity of spectators. As a consequence, it was completely ruled out when the size of the project was increased, as a structural solution based on concrete would not be possible because of the structure's weight and the resulting cost of construction.

The typological bases and the design of the current project are varied, and authors mention one in particular while establishing a possible influence of Emilio Pérez Piñero, which can be found in the letters that both of them wrote to each other at that time about the structure of the Sports Palace. Jose María Churtichaga refers to it in his publication, mentioning that "the dome is formed by two transverse families of arches formed by the intersection of the sphere with cutting planes passing through the pole of the same" (Churtichaga, 2008), Miguel Seguí also mentions that, as an advice "Pinero indicated Candela the opportunity of passing the planes of the arches (sphere sections) through the south pole instead of through the middle of the sphere" (Seguí, 2004), an influence that cannot be confirmed in the constructed project for the impossibility to verify geometrically its support, as the sections of the arches are based on great circles of a sphere-sections that pass through the center of the sphere-, which forced the center of the circle to be the same as the center of the sphere, because when considering that one section passes through the south pole of the sphere, it would require that the sections of the arches were of a variable measure, complicating its manufacture. Candela achieved it with great circles, constructed with sections of $5 \mathrm{~m}$, which were constant. Therefore, their prefabrication -an important criteria, considering the short time for their construction, and the actual situation of the Mexican construction industry at that time- was made simpler.

But a great part of the development of Candela's project was not only based on the recommendations of his friend Emilio Seguí in his book "Félix Candela y Emilio Pérez Piñero. Un diálogo imaginal. Proyecto para el concurso del velódromo de Anoeta"; Casinello, in her article "Félix Candela. En memoria (1910-1997). Del cascarón de hormigón a las estructuras ligeras del s. XXI" (Cassinello et al., 2010); and Del Cueto, in his article "Cien años de Félix Candela. Vuelos impensados" mentioned a great influence by various authors as Makowski, Shukhov, Fuller and Chritchlow, of whom Candela had magazines, extracts, reprints of several articles and books in his personal library, mainly about metal structures, studies and geometric analyses of the decomposition of the sphere and reticular typologies. Also, builders like Arup, Freyssinet, Dischinger, Finsterwalder, Nervi, Torroja, and Maillart, had an influence over his work, the last three being considered the masters of Candela. Being the laminar concrete structures of the European School the ones that attracted Candela's attention in his youth (Del Cueto Ruiz-Funes, 2009) and those that would influence his professional career, their legacy would be present in his first proposal of the project of the Sports Palace presented to the SOP, which later had to be modified due to the extension of spectators for the final project required in the competition. Thus, Candela chose a structural system where there was no problem between the expansion of the ground plan and section, taking as an example previous constructions and experiments carried out in concrete, such as the auditorium of the MIT by Eero Saarinen.

Figure 8. a) Elevation draft of the Sports Palace by Félix Candela (Fernández Contreras, 2011) b) Final elevation project. Source: Self-elaboration (2015). Comparing a ratio scale of the elevations.

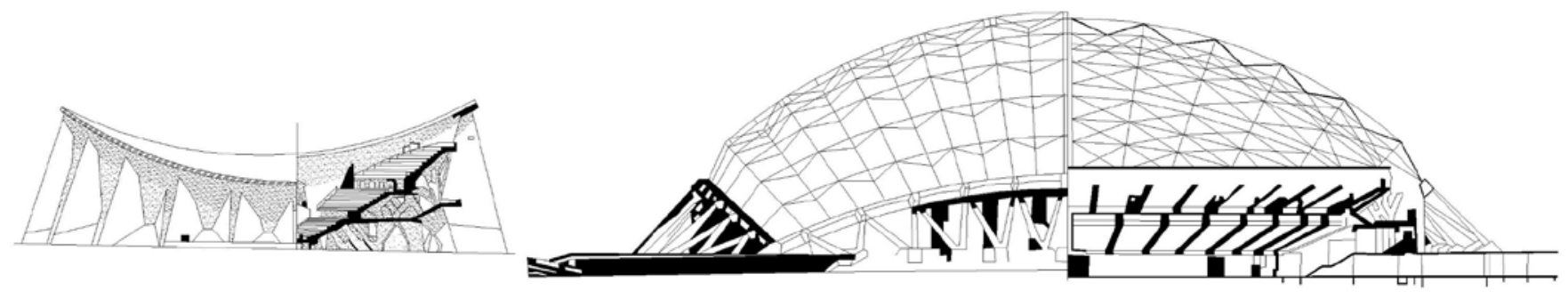

Given the influence of the mentioned authors, researchers and builders of the early twentieth century and the postwar world, as well as the knowledge of the bases for the development of buildings for the precedent structures for the XIX Olympic Games, it can be determined that these might have played an important role in the development of the constructed typology in the Sports Palace, based on the following factors for its analysis: the geometric shape of the dome 
as a structural solution to cover an area of great spans; the typology of the employment of great circles of a sphere using crossed arches to form the spherical grid; the use of the hyperbolic paraboloid as secondary structural solution to cover the dome of the Palace; and finally, the use of different materials for the manufacture of the structure, being the most important steel, aluminum, wood and copper (Figure 7).

The design of the grid of crossed arches for the solution of the Sports Palace can be observed in the approach for the structural solution of single curve grid shells, patented in 1895 by V. Shukhov, to design and build, later in the year of 1897, the first shell of double curvature for a steel structure company in the town of Vyksa, Russia. Subsequently, P.L. Nervi developed a type of barrel vault of crossed arches with a Lamella grid -system developed in 1906 by the German architect Zollinger from Dessau- of prefabricated elements for the structure of the Orvieto hangars, destroyed in the Second World War. The typology of the grid of crossed arches allowed Candela to stiffen the dome by preventing the movements in the structure, caused mainly by lateral loads, like wind and earthquakes, from destabilizing the structural system and thereby deforming the dome. Candela reassumed the linear solutions on a spherical surface by the use of arches, now employing the solution of crossed arches as bracing system.

Great circles of a sphere for the grid solution of the structure can be observed in previous works of domes such as the Discovery Dome structure in London for the British Festival in 1951, where great circles of a sphere where used forming a 3-way grid dome constructed out of aluminum, with a ring working in tension on the outside with a diameter of $104.2 \mathrm{~m}$. Another example where great circles of a sphere were employed -but, for the first time, forming a spherical grid- is the Hamman system (Hamilton and Manning), where metallic profiles of aluminum were used to form a single layer grid structure which, according to its inventors, could reach spans of $183 \mathrm{~m}$ and potentially up to $244 \mathrm{~m}$ (Pavilion for the exhibition of Toronto, 1950). Thus, aluminum becoming one of the new materials of the time and, from the mid-twentieth century, starting to be manufactured and used industrially due to its mechanical properties, a fact that Candela could take advantage of for the grid system of great circles, reaching a maximum span of the Sports Palace's dome of $193 \mathrm{~m}$, and he used aluminum as material of the secondary structure by leveraging that Eng. Castaño acquired the patent of the Triodetic system from Eng. Fentiman, allowing to obtain a construction system feasible to build and acquire in the country being a priority for the architect Candela, which at the same time was confirmed in an interview with PhD. Álvaro Sánchez, where he commented that the Triodetic node system is an option based on the node designed by Konrad Wachsmann, who would design a spatial structure for a hangar of large spans for the Navy of the United States of America.

Regarding the use of the hypar as part of the secondary structure of the deck, Candela had already made a similar previous exercise, in which he attempted to use these geometric elements in a tree structure in the project of the Crystal Palace in London in 1964. An important precedent using hypars in the solution of a dome is Gunter Gunschel, a studious architect who belonged to the category of architects conducting a research within the field of structures (Persitz, 1957), and who proposed and projected a metallic dome in the year of 1957, realized by using hypars that are part of a tetrahedron. This is a proposal that preceded the solution of the Sports Palace, and Candela showed a progress in resolving these geometric shapes for the solution of long-span structures, employing aluminum as the material for the secondary structure to the steel structure of the supporting arches, and using the Triodetic node to fabricate the hyperbolic paraboloid by straight lines on its main sides - a situation that was not that common- and also the connection of the secondary structure of aluminum would be hinged to the diagonals of the main steel structure by means of connectors that were separated by means of galvanized steel washers and would avoid the corrosion of steel to aluminum (Figure 5). This secondary aluminum structure would bear the creosoted plywood sheets, taking into account that the plywood solution was becoming a solution to use at the time. Not being regular its application under this condition, supporting the tile and forming the hypars -as they could be observed in some other structure- plywood was used with a folding that managed to get warped forms by means of attaching them to the aluminum structure using galvanized steel screws, together with staples for the union between sheets of plywood. Such solution would eventually allow the copper tiles to crimp between them, to prevent water to leak into the interior of the building, and also to be able to absorb the expansion of the material derived from temperature changes (Figure 7). 
The Sports Palace in Mexico City became a turning point and a typological model in the field of architecture not only in Mexico but also internationally, including personally for Félix Candela, for whom it was his last built project in Mexico. Candela noted that concrete shells -with the complexity of the new requirements of large-span projects and shapes that began to emerge- began to be replaced by light metal structures, given the adequacy of their new and modern construction methods to suit the new demands.

Candela used a dome-shaped structure that worked on axial compression, adopting a grid of crossed arcs in the shape of an orthogonal grid of spherical type which ensured to avoid deformations, as the form of the structure was stable enough to effectively absorb the mainly lateral loads. By using the arc as a structural element of the system, the structure was allowed to recover its shape against lateral external forces, as well as to maintain their compressive stress, providing a self-stabilizing response. Therefore, the arc solved the stability and the group of energetic dissipation against horizontal forces, where the structure was characterized as earthquake resistant by the transmission of forces to the foundation, allowing its stability. These arches, in combination with the aluminum structure, managed to lighten the weight of the structure by means of reducing the dead loads, also to gain the shape of hypars so kind to Candela. By means of use of the geometry characteristic of the simple constructive method of the hypar, the interior modules of the dome were designed inverted. This way, a constructive solution of simple work to tension attached to the diagonal arches was achieved, where they established a superficial set defined by balanced linear elements, braced by means of a tensioned surface of hypars in both curves - a solution already used by Frei Otto in Germany, but with a stretched skin of canvas. Candela used a surface totally in tension like a bracing system on the secondary structure.

Several researchers and builders of the twentieth century in the world as Albert Kahn, Robert Le Ricolais, R. Buckminster Fuller, Eduardo Catalano, Konrad Wachsmann and Frei Otto besides Félix Candela amongst others, manage to show the way that begins to emerge in middle of the twentieth century and in the following years on the development of the new structures and with the projects like the Dorton Arena, Discovery Dome, Astrodome and the large hangars mark the starting point in the change of the long-span and lightweight structures, factor that Candela fail to propose a lightweight structure that is capable of solving the different factors and then need that the SOP of the D.F. imposed with the requirements identified to the project and the land chosen for its construction. That's why the design of the Sports Palace and its construction becomes a typological model who come to consolidate by using complex geometries using new materials and construction systems, which subsequently it would develop and evolve in later years, resulting in more efficient structures to be constructed as will be the diagrid of the late of the twentieth century and the node systems for the construction of space structures of freeform shapes. 
Álvarez, J. R., \& González Pozo, A. (1968). Palacio de los Deportes. La Arquitectura Y El Deporte, 52-59.

Antonio, M. (2015). Palacio de los Deportes. Retrieved January 1, 2015, from www.mexicoenfotos.com.mx

Bradshaw, R., Campbell, D., Gargari, M., Mirmiran, A., \& Tripeny, P. (2002). Special Structures: Past, Present, and Future. Journal of Structural Engineering, 128(6), 691-709. https://doi.org/10.1061/(ASCE)0733-9445(2002)128:6(691)

Candela, F. (1954). Stereo-Structures. Progressive Architecture, 84-93.

Candela, F. (1958). Undestanding the hyperbolic paraboloid. Architectural Record, 191-195.

Candela, F., Castañeda, E., \& Peyrí, A. (1968). Proyecto arquitectónico del Palacio de los Deportes. Ingenieria, 38(4), 429-440.

Candela, F., Peyri, A., \& Castañeda, E. (1967). Hacia la XIX Olimpiada. Palacio 68. Calli Internacional, (30), 28-32.

Candela, F., Peyrí, A., \& Castañeda, E. (1968). Palacio de los Deportes. Informes de La Construcción, (205), 6-12.

Cassinello, P., Schlaich, M., \& Torroja, J. A. (2010). Félix Candela. En memoria (1910-1997). Del cascarón de hormigón a las estructuras ligeras del s. XXI. Informes de La Construcción, 62(519), 5-26. https://doi.org/10.3989/ic.10.040

Churtichaga, J. M. (2008). La estructura veloz. Revista Consejo Superior Colegios Arquitectos de España.

Comite Organizador de los juegos olimpicos XIX. (1968). Carta Olimpica 19. México 68. Avance de obras: Palacio de los Deportes. (Beatrice T).

Comite Organizador de los juegos olimpicos XIX. (1969). México 68.

Damy Rios, J. E. (1968). Utilización de las computadoras electrónicas en el análisis del Palacio de los Deportes. Ingenieria, 38(4), $462-481$.

De Buen, O. (1968). Estructura de acero de la cubierta del Palacio de los Deportes. Ingenieria, 38(4), 456-461.

De Miguel, C. (1968). Palacio de los Deportes. Arquitectura, (116), 10-14.

De Pablo, F. (1968). Palacio de los Deportes. Procedimientos de construcción. Ingenieria, 38(4), 492-507.

Del Cueto Ruiz-Funes, J. I. (2009). Cien años de Félix Candela. Vuelos impensados. Revista de La Universidad de México, (69), 82-90.

Fernández Contreras, R. A. (2011). Los concursos de arquitectura en el marco de los juegos olímpicos de México '68. Organización, propuestas y valoración de resultados. (Thesis). Universidad Nacional Autonoma de México, México, D.F.

Ferrada, X., \& Serpell, A. (2009). La gestión del conocimiento y la industria de la construcción. Revista de La Construcción, 8(1), 46-58.

Guerrero V., G. (1968). Proyecto estructural del Palacio de los Deportes. Ingenieria, 38(4), 445-455.

Makowski, Z. S. (1984). Analysis, design, and construction of braced domes. Nichols Pub. Co.

Meli, R., Olivares, A., \& Esteva, L. (1968). Palacio de los Deportes. II. Ensaye de modelos estructurales de la cubierta. Ingenieria, 38(4), 546-574.

Meza, E., \& Diaz, J. (2013). Shapes and behavior of triangular grid structures. Current trends in architecture of the 21th Century. In P. J. S. Cruz (Ed.), Structures and Architecture (pp. 1395-1402). Conference Proceeding, Guimaraes. https://doi.org/10.1201/b15267-194

Moreno Aguirre, R. F. (1969). Supervisión y construcción del Palacio de los Deportes (Thesis). Facultad de Ingenieria. Universidad Nacional Autonoma de México, México, D.F.

Murad Silva, C. A. (1967). Construcción del Palacio de los Deportes. Revista Mexicana de Ingeniería Y Arquitectura, 47(4), 28-39.

Ochoa, L., \& Osorio, E. (1985). Y siguen surgiendo inventores mexicanos. Contenido, 54-59.

Persitz, A. (1957). Gunther Gunschel. L'architecture D'aujourd'hui, 73.

Ruiz Hernandez, D. (1968). Criterios de Diseño. Ingenieria, 38(4), 441-444.

Schueller, W., Heck, A., \& de Strasbourg, O. (1983). Horizontal-span building structures. John Wiley \& Sons, Inc.

Seguí, M. (2004). Félix Candela y Emilio Pérez Piñero. Un dialogo imaginal. Proyecto para el concurso del velódromo de Anoeta. Rueda S.L.

Sotelo A., G., \& Springall G., R. (1968). Palacio de los Deportes. I. Estudio del efecto del viento sobre la estructura. Ingenieria, 38(4), 533-546.

Velázquez Moreno, H. (1968). Descripción Arquitectónica de las instalaciones Olímpicas ejecutadas por la Secretaría de Obras Públicas. Ingenieria, 38(4), $415-428$.

Villasana Suverza, C. (2015). Palacio de los Deportes. Retrieved January 1, 2015, from http://www.mexicoenfotos.com.mx 